\title{
Trust in God and/or Science? Sociodemographic Differences in the Effects of Beliefs in an Engaged God and Mistrust of the COVID-19 Vaccine
}

\author{
Laura Upenieks $^{1} \cdot$ Joanne Ford-Robertson ${ }^{2} \cdot$ James E. Robertson $^{3}$
}

Accepted: 12 November 2021 / Published online: 29 November 2021

(C) The Author(s), under exclusive licence to Springer Science+Business Media, LLC, part of Springer Nature 2021

\begin{abstract}
At present, COVID-19 vaccines are widely available in the USA, but large proportions of the American populace remain unvaccinated. One possible source of COVID-19 vaccine hesitancy is a lack of trust in science. In this study, drawing from the large literature at the intersection of science and religion, we ask whether beliefs in an engaged God (the belief that God is involved in daily human affairs) predict mistrust of the COVID-19 vaccine and whether any observed association differs across race, gender, and education. Using nationally representative data from Wave 6 of the Baylor Religion Survey (2021), our results suggest that beliefs in an engaged God were associated with greater mistrust in the COVID-19 vaccine. This association was amplified for Hispanic and lower educated Americans. We argue that beliefs in an engaged God may promote a distrust of science, reduce motivation to get vaccinated, and derive comfort and strength by placing control over one's life in the hands of a loving, involved deity. We also situate our findings within an emerging body of work on the "dark side" of religion and reflect on their implications for understanding the broader religion/health connection.
\end{abstract}

Keywords COVID-19 vaccine $\cdot$ Engaged God $\cdot$ Race $\cdot$ Gender $\cdot$ Education . Science $\cdot$ Health locus of control

Laura Upenieks

laura_upenieks@baylor.edu

1 Department of Sociology, Baylor University, One Bear Place, Waco, TX 76798, USA

2 Department of Sociology, University of Texas, San Antonio, USA

3 San Antonio, TX, USA 


\section{Introduction}

Since its onset in the early months of 2020, the COVID-19 global pandemic has exacted a steep toll on human lives, health care systems, social well-being, and the global economy (Wilder-Smith \& Freedman, 2020). For most countries, the development of a safe and effective vaccination against the coronavirus was seen as the long-term solution to the pandemic, and this was made possible by the introduction of several vaccines in the early months of 2021. At present, COVID-19 vaccines are widely available in the USA, but large proportions of the American populace remain unvaccinated. According to the Centers for Disease Control and Prevention, weekly vaccination rates peaked in April of 2021 when vaccine eligibility was opened to all adults and within three months had plateaued at just over $50 \%$ of the population 12 years and older (CDC, 2021). The goal of widespread vaccination is to reach "herd immunity," which occurs when the virus does not incubate and continue spreading from one person to another (Randolph \& Barreiro, 2020). Theoretically, effective herd vaccination requires $55 \%$ to $82 \%$ of the population to be vaccinated according to recent estimates (De Roo, Pudalov, \& Fu, 2020). Therefore, a critical step in extinguishing the pandemic will be understanding factors that lead Americans to make the decision not to get the COVID-19 vaccine. According to a study of 39 nationally representative polls taken in the beginning of 2021, approximately one-third of the US population was skeptical or unwilling to take the vaccine (SteelFisher et al., 2021), so work remains to be done to understand reasons for this hesitance.

One possible source of COVID-19 vaccine hesitancy is a lack of trust in science (Edwards et al., 2021). In this study, we proactively investigate the predictors of (mis)trust in the COVID-19 vaccine. Though there are several factors that may predict mistrust in the COVID-19 vaccine, it is well established that religious groups tend to have less confidence in science (Evans, 2013; Gauchat, 2012). An oft-cited reason to explain the tendency of some religious believers to hold a lack of faith in science is the unyielding belief in God, which is cemented by the belief that God will protect His believers from any harm. This may portend less trust in science or reduce compliance with medical advice to get vaccinated against the coronavirus, as this may be viewed as unnecessary steps to take because they "have God" (DeFranza et al., 2020; Wu \& Cutright, 2018).

Against this backdrop, it is important to acknowledge that the USA has been identified as an exceptional case when it comes to religion and beliefs in God. First, more than $90 \%$ of Americans believe there is a God (Pew Research Center, 2014). Second, most Americans subscribe to a belief in a personal and influential God who is intimately involved and engaged in their lives (Froese \& Bader, 2010). The belief in an engaged God is summarized by Smith (2007, pg.168) in the following description: "everything existent is already held in the lovingly cupped hands of a personal, attentive God who listens, who knows, who remembers, who answers, who is coming home, and who will in time make all these things right." Schieman and colleagues (2006) echo the sentiments of Smith (2007) and crystallize these beliefs into a concept of "divine control," that "God exerts a commanding authority over the 
course and direction of one's life, that God controls the good and bad aspects of one's life, that God has decided what one's life shall be, and that one's fate evolves according to God's will" (pp.519).

In this study, we undertake two research objectives that center on beliefs in God's causal involvement in human life. First, drawing from the large literature at the intersection of science and religion, we ask whether beliefs in an engaged God predict a lack of trust in the COVID-19 vaccine. Second, recognizing that this pattern is unlikely to be consistent across sociodemographic characteristics, which themselves also predict attitudes toward the COVID-19 vaccine (Mohan et al., 2021; Olagoke et al., 2021; Piltch-Loeb et al., 2021; Sallam, 2021; Viswanath et al., 2021) and are linked with beliefs in God's causal influence over daily life (Bonhag \& Upenieks, 2021; Hayward et al., 2017; Lincoln \& Mamiya, 1990; Schieman, 2010; Schieman \& Jung, 2012), we consider how race, gender, and social class (education) may moderate the association between beliefs in an engaged God and COVID-19 vaccine hesitancy. For the disenfranchised members of American society, the belief in an engaged, involved God may lead them to freely draw on a limitless source of power that they can cede control to, including over their health and risk of COVID19 infection. Beliefs in an engaged God may be an important determinant of vaccine (mis)trust, that, through yet to be studied, could have the negative consequence or prolonging the existential threat of the virus in the USA.

\section{Background}

\section{Beliefs in an Engaged God and Mistrust of the COVID-19 Vaccine}

Our central argument is that religious believers who hold strong beliefs in an engaged God may be especially likely to distrust the COVID-19 vaccine. Such persons may hold more negative views of science and scientists and have strong religious beliefs concerning the pandemic itself. Indeed, several studies show that more religious populations tend to report less trust in science as a social institution and more antiscience attitudes (Evans, 2013; Gauchat, 2012) and hold negative views toward scientific innovations and nanotechnology (Cacciatore et al., 2018; McPhetres \& Zuckerman, 2018). To be sure, these findings are not equally applicable to all religious groups. There is some evidence to suggest that more conservative Protestant denominations may be less literate in science and empirically critical of the entire scientific community and skeptical of scientific progress (Ellison \& Musick, 1995; Evans, 2013; Sherkat, 2011), as they tend to see the Bible as the ultimate source of authority when interpreting personal life and world events (Ellison \& Musick, 1995). ${ }^{1}$

\footnotetext{
1 Though religious denominational differences in COVID-19 vaccine mistrust are not the central focus of this study, we note that both Catholicism and mainline Protestantism have mechanisms for synthesizing science and theology, so any contemporary conflict of knowledge with science would only be with white evangelicalism or fundamentalism (Evans, 2018). This conflict tends to be over a few narrow claims, mostly concerning the creation of the world and human origin (Evans \& Hargittai, 2020). Although conservative Protestants have the intellectual ability to oppose a particular scientific claim, including those related to the efficacy of the COVID-19 vaccine, there are not alternative conservative
} 
Tensions between religion and science often stem from fears concerning the profane influence of science on society (Evans, 2013), and "a social conflict between institutions struggling for power" (Evans \& Evans, 2008, pp.97). ${ }^{2}$ Conceptually related to the present research, a recent study by Johnson and colleagues (2021) looked at how "faith" and "science" mind-sets predicted COVID-19 concern during the early months of the pandemic. Using the faith/science mind-set scale developed by Kitchens and Phillips (2018), respondents from the USA were asked to rate their agreement with the following statements during the early months of the pandemic (March 2020): "I trust that Science [God] can solve the major problems of humanity," and "Relying on information from Science [God] can solve the major problems of humanity." Johnson and colleagues (2021) found that only the science mind-set was predictive of reporting COVID-19 concern. However, more importantly for the purposes of the current study, holding a faith mind-set was a strong, negative predictor of a science mind-set (Pearson's $r=-0.61$ ).

Though a faith and science mind-set are not necessarily incompatible, the belief that God provides comfort, protection, or help in daily life could lead individuals to be less concerned with getting vaccinated. Related research finds that religious believers use intuition more than do non-believers (Pennycook et al., 2012; Shenhav et al., 2012). Moreover, work in social psychology shows that experimentally inducing people to adopt an analytic mind-set decreases subsequent religious belief (Gervais \& Norenzayan, 2012). Therefore, holding strong beliefs in an engaged/interventionist God could be, at least to some extent, at odds with analytical thinking around issues related to science and the evidence surrounding the COVID-19 vaccine.

The specific flashpoints we highlight in the current study that may underlie mistrust of the COVID-19 vaccine are beliefs that God is the ultimate arbiter of life and death. There are some Biblical passages within the Christian Bible that may support the adoption of a faith mind-set, helping to advance the position that God is "bigger than" the coronavirus. For instance, the Book of Joshua (1:9) says: "Be strong and courageous. Do not be frightened, and do not be dismayed, for the Lord your God is with you wherever you go." One way in which religious believers may face an uncertain health future during the pandemic is to derive strength and courage from God with the knowledge that He is involved and engaged, rather than to take a vaccine.

The notion that an involved and engaged God will protect His believers from illness may uniquely position individuals holding this belief to mistrust the vaccine. Extant research suggests that religiosity, defined in broad strokes, tends to be a strong predictor of anti-vaccine beliefs (Mahdi et al., 2016). A common determinant

\footnotetext{
Footnote 1 (continued)

Protestant claims about virology and epidemiology, so we would not necessarily expect this group to be less trusting of the COVID vaccine. Supplemental analyses (reported after the presentation of our main results) show this to be the case.

2 Some existing research shows that many Americans see the belief systems of science and faith as conflicting domains, often in terms of an epistemological divide (McPhetres \& Nguyen, 2018; McPhetres, Jong, \& Zuckerman, 2021; O'Brien \& Noy, 2015). However, to be sure, science and faith mindsets do not necessarily conflict, as people can and do often rely on both religious and scientific beliefs (Ecklund \& Scheitle, 2017).
} 
of vaccine acceptance among religious people is what has been referred to as the health locus of control (HLOC) (Amit-Aharon et al., 2018; Sinding-Bentzen, 2019). The HLOC is the extent of the perception that one has control over their health through their own actions, with two opposing loci identified as internal and external LOC (Wallston, 2005). Individuals who believe they can positively influence their health outcomes (internal HLOC) may actively seek preventive medical treatment, such as vaccination. However, those with an external HLOC believe that their health depends on external factors such as God, chance, or powerful others. This could have implications for vaccine uptake, as one prior study found that among highly religious patients, an external HLOC was associated with low childhood vaccine uptake through patients' attitudes (Amit-Aharon et al., 2018).

How might beliefs in an engaged God affect the health locus of control? We make an important distinction here that beliefs in an engaged, involved God are not identical to beliefs in an external health locus of control. Nevertheless, weighing the virulent nature of COVID-19 against the evidence that religious individuals may offer explanations to a crisis by referencing it as an "Act of God" (Sinding-Bentzen, 2019) over which humans have no control might lead those holding this view to not take precautionary measures. Though unspecific to beliefs in an engaged God, Olagoke and colleagues (2021) found that religiosity was significantly and negatively associated with the intention to vaccinate against COVID-19 and holding an external HLOC was a mediating pathway through which this association operated.

Religious beliefs about health can be described as externalizing when they shift the responsibility for one's health outcomes away from the self and toward God or other supernatural forces. These beliefs may enhance feelings of well-being, at least temporarily, by reinforcing the perception that God is in control during chaotic times (Upenieks, Bierman \& Schieman, 2021), but they may undermine other aspects of health by diminishing the motivation to engage in preventive health behaviors, such as getting vaccinated by shifting responsibility for health outcomes toward external forces and away from the self (e.g., Debnam et al., 2012). A strong sense of divine control over health has been found to be related to negative health outcomes (Franklin et al., 2007, 2008), possibly because divine control is related to a diminished sense of personal control (Schieman et al., 2005, 2018). Thus, to the extent that beliefs in an engaged God who is involved in human affairs portend an external locus of health control and attributing the pandemic to sources beyond the control of human beings, we might expect them to be associated with greater mistrust in the COVID-19 vaccine:

Hypothesis 1 Stronger beliefs in an engaged God will be associated with greater mistrust of the COVID-19 vaccine.

\section{Beliefs in an Engaged God, Sociodemographic Characteristics, and Mistrust of the COVID-19 Vaccine}

Race/ethnicity, gender, and social class are important to assess in an analysis of trust in the COVID-19 vaccine, as several studies have shown both intent to get 
vaccinated and vaccine uptake to vary across these key sociodemographic indicators. In what follows, we summarize the existing evidence on how each of these characteristics influences attitudes toward the COVID-19 vaccine, and more centrally, how beliefs in an engaged God might operate differently to generate varying degrees of mistrust in the vaccine across different groups.

\section{Race/Ethnicity}

One of the most consistent sociodemographic predictors of vaccine uptake and acceptance in the USA is race. Scores of studies have shown that compared with Whites, Black populations are much less likely to receive vaccines (Galbraith et al., 2016; Webb et al., 2018) or to trust the government and health care providers such as pharmaceutical companies (Allen \& de Jesus et al., 2012; Galbraith et al., 2016; Whitehead \& Perry, 2020), with some variability within Hispanic populations. A lack of knowledge about vaccines can be vital to explaining various racial gaps (Burdette et al., 2014; Galbraith et al., 2016), as well as a broader distrust connected to historical abuses by medical professionals (O'Donnell, 2019; Williams \& Mohammed, 2009). In one summary, Sullivan (2020) notes: "there is ample evidence that patient mistrust toward the American medical system is to some extent associated with communal and individual experiences with racism" (pg.18).

Given their propensity to mistrust medical science and medical care, we would already expect Black and Hispanic Americans to report greater mistrust and lower uptake of the COVID-19 vaccine. And indeed, this is what has been found in recent research efforts (Bogart et al., 2021; Khubchandani et al., 2021; Olagoke et al., 2021; Viswanath et al., 2021). We may expect this relationship to be exacerbated for Blacks and Hispanics who believe in an engaged God, which we expand on in turn below.

When it comes to African Americans, race overlaps with religious background in ways relevant to health beliefs. Members of this racial group are more likely to report health fatalism (Egede \& Bonadonna, 2003) and are more likely to feel that their health outcomes are beyond their control (Franklin et al., 2008), lowering their motivation to take steps to improve health (Franklin et al., 2007). Blacks tend to have a greater deferral of health control to God (Hayward et al., 2017), therefore believing that divine interventions may concern medical ailments or the body. This is unsurprising given that the faith traditions of many African Americans have emphasized the importance of constructing a deep, personal relationship with an involved and gracious God (Washington, 1994). Central to most African American church traditions is a view of God as interacting with humans on a personal level, and His guiding hand is vital to maintaining well-being under distressing circumstances (Lincoln \& Mamiya, 1990). African Americans have found to hold stronger beliefs in an engaged God relative to their White counterparts (Krause, 2005; Schieman et al., 2006). Thus, African Americans holding beliefs in an engaged God may be even more likely to report distrust in the vaccine, instead choosing to place their trust in God to deliver them in good health without intervention from a medical system they place little trust in. 
The existing evidence also suggests that religiosity plays an important role in perceptions of health control among Hispanic Americans (Flórez et al., 2009; Ransford et al., 2010). While Hispanic people in the USA do not tend to perceive the same historical maltreatment from the healthcare system as African Americans, other factors including lack of access to health insurance, immigration status, and language barriers also lead them to occupy a marginalized status (Ransford et al., 2010), which may contribute to beliefs in health fatalism and a stronger sense that God is in control of one's health compared to Whites (Chavez et al., 1997; see also Boyd \& Wilcox, 2020).

Among Hispanic Americans, there also tends to be a pronounced conviction that God will grant them good health if they have sufficient faith (Schieman \& Jung, 2012). This line of thinking highlights a faith-based form of health prevention and health, which is a driving force behind the growing number of Latino Protestants in the USA, two-thirds of whom self-identify as Pentecostal or Charismatic (Espinosa, 2011). Therefore, informed by this prior research, we hypothesize:

Hypothesis 2a The association between beliefs in an engaged God and mistrust of the COVID-19 vaccine will be amplified for African Americans relative to Whites.

Hypothesis $2 b$ The association between beliefs in an engaged God and mistrust of the COVID-19 vaccine will be amplified for Hispanic Americans relative to Whites.

\section{Gender}

Existing evidence on gender and COVID-19 vaccine hesitancy is mixed, with some studies finding women to be more hesitant to the COVID-19 vaccine (Mohan et al., 2021; Piltch-Loeb et al., 2021; Sallam, 2021) and some less hesitant (Khubchandani et al., 2021; Olagoke et al., 2021; Viswanath et al., 2021) than men. Vaccine hesitancy in females tends to be attributable to concerns about the safety of vaccination in the context of pregnancy and breastfeeding (Mohan et al., 2021), though it is important to note that women tend to be more confident and supportive of science than men (Evans, 2013; Evans \& Feng, 2013).

Gender might intersect with beliefs in an engaged God in a unique way, though we do not expect this modifying effect to be as strong as race (described above) or social class (described below). Women tend to have stronger beliefs in divine control and God's engagement in daily affairs (Schieman et al., 2010). Women also tend to hold more favorable views of God compared to men and are more likely to conjure positive and loving images of God (Bonhag \& Upenieks, 2021; Jung, 2020). Moreover, women are likely to have a stronger God locus of health control relative to men (Boyd \& Wilcox, 2020). Thus, we might expect gender to also strengthen the association between beliefs in an engaged God and COVID-19 vaccine hesitancy.

Hypothesis 3 The association between beliefs in an engaged God and mistrust of the COVID-19 vaccine will be amplified for women relative to men. 


\section{Social Class (Education)}

Most studies show that those with more education support science more than those with less education. This is usually interpreted as a result of familiarity with science, not class position (Evans, 2011; Evans \& Hargittai, 2020; Gauchat, 2012). ${ }^{3}$ A lower education has been found to be associated with a lower likelihood of receiving the COVID-19 vaccine (Piltch-Loeb et al., 2021).

The connection between social stratification and religious belief has long been of interest in sociological research (Marx, 1844/1978; Schieman, 2010; Schieman \& Jung, 2012; Upenieks \& Schieman, 2021). These findings are in concert with the deprivation-compensation perspective, which proposes that people with greater vulnerability to financial and material threats are more likely to turn to religion to both explain and cope with their current circumstances. The weight of available evidence suggests that individuals with a lower socioeconomic status are more likely to endorse the belief in an engaging, responsive, and intervening God or other supernatural agents (Draper \& Baker, 2011; Krause, 2005; Schieman, 2010).

On the other hand, however, having what they need and feeling a sense of personal efficacy to achieve it on their own, more educated people are less likely to endorse beliefs in an engaged God (Schieman, 2010). With increasing educational achievements, individuals attain a greater knowledge of science and develop a critical and mechanistic worldview (Van Tubergen \& Sindradottir, 2011), honing critical thinking skills in the process that might lead them to rely less on religious explanations in daily life. As it relates specifically to control over health, individuals with lower education might have a weaker sense of health-related control because they have access to fewer resources to influence their health outcomes. These individuals could be attracted to religious worldviews, such as deferring control over their health to a divine being, to given them alternative forms of control (Hayward et al., 2017). Thus, for the lower educated, already hesitant to be vaccinated against COVID-19, beliefs in an engaged God that is in control of their life may further cement this position, and lead to heightened mistrust:

Hypothesis 4 The association between beliefs in an engaged God and mistrust of the COVID-19 vaccine will be amplified for the less educated relative to the well-educated.

\footnotetext{
${ }^{3}$ Family income is not a strong predictor of science views and is not significant in many survey studies (Evans, 2013; Evans \& Feng, 2013; Gauchat, 2015). With 30,000 cases, Gauchat (2012) did not find that those with lower incomes show lower levels of confidence in those who lead institutional science. For these reasons, then, we focus on education as in indicator of socioeconomic status with possible linkages to trust in the COVID-19 vaccine in the current study.
} 


\section{Data and Methods}

Data from this study come from the Values and Beliefs of the American Public Survey (Baylor Religion Survey, Wave 6). This study was based on a mail and web survey conducted January 27-March 21, 2021, with a random sample of 1,248 adults ages 18 and older, living in all 50 states and the District of Columbia. Gallup randomly selected individuals to participate using an address-based sample (ABS) frame. Respondents had the opportunity to respond to the survey via web or paper. Surveys were conducted in English and Spanish. The final response rate to this survey was $11.3 \%$ (AAPOR1).It is worthy of mention that the survey was fielded during the COVID-19 pandemic. Many areas experienced significant postal delays related to the pandemic. This likely had an impact on response rates, and Gallup did see a significant decline in response rates on other mail surveys fielded during the pandemic.

Samples were weighted to correct for unequal selection probability and nonresponse. Demographic weighting targets are based on the 2020 American Community Survey figures for the 18 and older population. The data were weighted to match national demographics of age, education, gender, race, ethnicity, and Census region.

Since our analyses centered on beliefs in an engaged God, we note that the items comprising this scale were only asked of BRS respondents who reported believing in God $(N=920)$. Of those respondents eligible to answer the questions related to God, 877 provided valid data on all study variables after using listwise deletion to address missing data (since less than $5 \%$ of all eligible cases had missing data).

\section{Dependent Variable: Mistrust of the COVID-19 Vaccine}

As a measure of (mis)trust in the COVID-19 vaccine, respondents were asked to rate their agreement with the following question: "A vaccine for COVID-19 should not be trusted." Responses were coded according to the following scheme: 1= "Strongly disagree, 2="Disagree," 3="Neither agree nor disagree," 4="Agree/Strongly Agree" (the latter two categories were combined to achieve adequate cell size).

\section{Focal Independent Variables}

Beliefs in an Engaged God were measured by summing responses to the following six questions (Froese \& Bader, 2010). The first four items were as follows and had the same coding scheme: (1) "God is directly involved in world affairs," (2) "God is concerned with my personal well-being," (3) "God is directly involved in my affairs" (4) God is concerned with the well-being of the world," (5) God seems impersonal to me (reverse-coded), and (6) Responses were coded so where 1= "Strongly disagree," 2="Disagree," 3="Agree," and 4="Strongly agree." The second two items of the engaged God scale gauged how well the following items described God, for the respondent: "ever-present" and "distant" (reverse-coded). Responses 
were categorized according to the following four-item coding scheme: $1=$ "Not at all," 2="Not very well," 3= "Somewhat well," and 4="Very well." (Cronbach's alpha $=0.85$ ). After summation, this variable ranges from 6-24, and higher scores indicate stronger beliefs in an engaged God.

Race: In the BRS-6, race was coded as a four-category variable, where $1=$ White [reference category], $2=$ Black, non-Hispanic, $3=$ Hispanic, $4=$ Other Race.

Gender: Female was coded as $=1$, and male $=0$.

Education: Education was coded into a binary variable to distinguish respondents with and without a college degree, where $1=$ college degree or higher and $0=$ less than a college degree.

\section{Covariates}

Analyses adjust for several covariates that may also hold strong correlations both with beliefs in an engaged God and trust in the COVID-19 vaccine. First, we adjust for political party identification $(1=$ Strong Republican, $2=$ Moderate Republican, 3=Leaning Republican, 4=Independent, 5=Leaning Democrat, 6=Moderate Democrat, $7=$ Strong Democrat). "Strong Republican" serves as our reference category in all analyses. Past studies have found that political conservatives and those who identify with the Republican party are more skeptical of science (Gauchat, 2012). Americans who are politically conservative, either by ideology or party affiliation, tend to hold greater skepticism about vaccines and delay uptake (McCoy, 2020).

We also adjust for a measure of household income to ensure that any association between education and mistrust of the COVID-19 vaccine is not conflated by this additional measure of socioeconomic status. Income was coded as a seven-category variable according to the following designations: $1=\$ 10,000$ or less [reference category], $2=\$ 10,001-\$ 20,000,3=\$ 20,001-\$ 35,000,4=" 35,001-\$ 50,000$, $5=" 50,001-\$ 100,000, " 6=" 100,001-150,000$," and 7 = " 150,000 or more." We also adjust for age (years) and marital status (where those who are married are coded as 1 , all else $=0$ ).

Two measures serve as controls for individual religiosity and religious affiliation. First, we adjust for the frequency of religious attendance in the past year. Religious attendance was coded as follows: $1=$ "Never attends" [reference category], 2 = "Less than once a year," $3=$ "Once or twice a year," $4=$ "Several times a year," $5=$ "Once a month or more," and $6=$ "Once a week or more." We also feature a variable indicating respondents' religious affiliation according to a modified version of the RELTRAD scheme (Steensland et al., 2000; see Lehman \& Sherkat, 2018), ${ }^{4}$ which takes

\footnotetext{
${ }^{4}$ We follow advice from Lehman and Sherkat (2018, pg.782) for the coding of Black Protestants, where they note: "it is not appropriate to classify African American Protestants simply based on race as in Reltrad, where respondents who "don't know which" type of Methodist or Baptist they are or claim to be "other" Methodists or Baptists coded as black Protestants if they are coded as black on race indicators." Therefore, if respondents did not indicate being Evangelical Protestant, they were coded as Mainline Protestants.
} 
Mainline Protestant as the reference category and contrasts it with Evangelical Protestant, Catholic, Jewish, Other, and Non-affiliated.

Vaccine attitudes could also logically be influenced by one's own personal experiences with COVID-19 or those of a close family member (Piltch-Loeb et al., 2021). Thus, we include an adjustment for whether the respondent had COVID during the past year $(1=$ yes, $0=$ no) and whether they had a family member or friend die from COVID-19 ( $1=$ yes, $0=$ no).

Analyses also include an adjustment for region of the country that the respondent resides in, as this could influence political and cultural norms, as well as the extent of lockdowns or restrictions related to COVID-19. Northeast serves as our reference category, and is contrasted with the South, Midwest, and West regions of the USA.

\section{Plan of Analysis}

Since mistrust in the COVID-19 vaccine is an ordered, categorical variable, ordinal logistic regression models are used to test our hypotheses. Ancillary analyses showed that the proportional odds assumption was not violated (as evidenced by a non-significant Brant Test in Stata 15), so we could proceed with this model. Odds ratios and $95 \%$ confidence intervals are displayed in our table of results. Model 1 tests a baseline association between beliefs in an engaged God and mistrust of the COVID-19 vaccine. Models 2-4 then sequentially test an interaction term between beliefs in an engaged God and race, gender, and education, respectively. In several instances, we present predicted probabilities of agreeing/strongly agreeing that the COVID-19 vaccine cannot be trusted across group of interest using estimates derived from the margins command. We also present McFadden Pseudo $\mathrm{R}^{2}$ values to indicate the proportion of the variance in our outcome variable explained by the covariates in our model.

\section{Results}

Table 1 presents descriptive statistics for all study variables. The modal category for trust in the COVID-19 vaccine was strong disagreement that the vaccine could not be trusted $(42.35 \%)$. Roughly one-quarter of respondents disagreed that the vaccine could not be trusted, and $21.53 \%$ neither agreed nor disagreed that the vaccine could be trusted. Just over $10 \%$ of the sample either agreed or strongly agreed that the vaccine could not be trusted.

Moreover, the sample reported fairly strong beliefs in an engaged God, with a mean of 18.42 on a 24 -point scale, but with some variability (standard deviation =4.07). As for the sociodemographic characteristics of interest, $54.23 \%$ of the sample was female, and $11.46 \%$ of the sample was Black and $15.61 \%$ were Hispanic. In addition, $54 \%$ of the BRS-6 sample had a college degree or more. 
Table 1 Descriptive Statistics, 2021 Baylor Religion Survey (Wave 6) ( $\mathrm{N}=877$ )

\begin{tabular}{|c|c|c|c|c|}
\hline & Mean/\% & S.D & Minimum & Maximum \\
\hline \multicolumn{5}{|l|}{ Dependent variable } \\
\hline \multicolumn{5}{|c|}{ COVID-19 Vaccine Should Not be Trusted } \\
\hline Strongly disagree & 42.35 & & & \\
\hline Disagree & 25.71 & & & \\
\hline Neither agree nor disagree & 21.53 & & & \\
\hline Strongly agree/agree & 10.41 & & & \\
\hline \multicolumn{5}{|l|}{ Focal independent variables } \\
\hline Engaged God & 18.42 & 4.07 & 6 & 24 \\
\hline Gender $($ female $=1)$ & 54.23 & & 0 & 1 \\
\hline Race & 3.58 & 0.55 & 1 & 4 \\
\hline White, non-Hispanic & 65.77 & & & \\
\hline Black & 11.46 & & & \\
\hline Hispanic & 15.61 & & & \\
\hline Other Race & 7.15 & & & \\
\hline College educated & 0.54 & & 0 & 1 \\
\hline \multicolumn{5}{|l|}{ Controls } \\
\hline Political Party Identification & & & 0 & 1 \\
\hline Strong Republican & 7.35 & & & \\
\hline Moderate Republican & 12.02 & & & \\
\hline Leaning Republican & 8.85 & & & \\
\hline Independent & 28.38 & & & \\
\hline Leaning Democrat & 10.12 & & & \\
\hline Moderate Democrat & 16.52 & & & \\
\hline Strong Democrat & 16.76 & & & \\
\hline Marital status $($ Married $=1)$ & 51.40 & & 0 & 1 \\
\hline Age & 54.88 & & 18 & 98 \\
\hline Household Income & & & 0 & 1 \\
\hline$\$ 10,000$ or less & 5.47 & & & \\
\hline$\$ 10,001-\$ 20,000$ & 8.86 & & & \\
\hline$\$ 20,000-\$ 35,000$ & 12.76 & & & \\
\hline$\$ 35,001-\$ 50,000$ & 15.00 & & & \\
\hline$\$ 50,000-\$ 100,000$ & 26.76 & & & \\
\hline$\$ 100,000-\$ 150,000$ & 15.66 & & & \\
\hline$\$ 150,000$ or more & 15.49 & & & \\
\hline Religious Attendance & & & 0 & 1 \\
\hline Never attends & 34.78 & & & \\
\hline Less than once a year & 11.29 & & & \\
\hline Once or twice a year & 10.97 & & & \\
\hline Several times a year & 8.92 & & & \\
\hline Once a month or more & 8.10 & & & \\
\hline Once a week or more & 25.94 & & & \\
\hline Religious Affiliation & & & & \\
\hline
\end{tabular}


Table 1 (continued)

\begin{tabular}{|c|c|c|c|c|}
\hline & Mean $/ \%$ & S.D & Minimum & Maximum \\
\hline Mainline Protestant & 21.30 & & & \\
\hline Evangelical Protestant & 24.76 & & & \\
\hline Black Protestant & 7.80 & & & \\
\hline Catholic & 24.84 & & & \\
\hline Jewish & 2.41 & & & \\
\hline Other & 8.36 & & & \\
\hline Non-affiliated & 18.33 & & & \\
\hline Respondent had COVID & 16.92 & & & \\
\hline $\begin{array}{l}\text { Respondent lost family member/ } \\
\text { friend due to COVID }\end{array}$ & 24.70 & & & \\
\hline \multicolumn{5}{|l|}{ Region of the USA } \\
\hline Northeast & 16.25 & & & \\
\hline South & 38.15 & & & \\
\hline Midwest & 20.92 & & & \\
\hline West & 24.68 & & & \\
\hline
\end{tabular}

Standard deviations are omitted for categorical variables

\section{Multivariable Analyses}

Table 2 shows results from a series of four models designed to test our study hypotheses. Model 1 of Table 2 shows the baseline association between beliefs in an engaged God and mistrust of the COVID-19 vaccine, net of all study covariates. We find evidence that beliefs in an engaged God were associated with greater odds of mistrust in the vaccine $(\mathrm{OR}=1.05, p<0.05)$. An analysis of average marginal effects shows that those with strong beliefs in an engaged God (one standard deviation above the mean) had a 5\% greater chance of falling into the "strongly agree/agree" category of mistrust in the vaccine (13\%) compared to those with lower beliefs in an engaged God (at one standard deviation below the mean) (8\%) and those at the mean level of beliefs in an engaged God (10\%). This result supports Hypothesis 1, which proposed that stronger beliefs in an engaged God would be associated with greater mistrust in the vaccine.

It is also notable within Model 1 that of the sociodemographic variables focal to our study, only a college education was significantly associated with trust in the vaccine, in the expected direction. Indeed, those with at least a college education were less likely to mistrust the vaccine $(\mathrm{OR}=0.46, p<0.001)$. Neither race nor gender was associated with mistrust in the vaccine, the former result which appears to be inconsistent with previous research (Mohan et al., 2021; PiltchLoeb et al., 2021), though we note that we are predicting (mis)trust in the vaccine and not the intention to be vaccinated or actual vaccination uptake. These null results, however, do not preclude the possibility that race, gender, or education may combine with beliefs in an engaged God to produce differential probabilities of trust in the COVID-19 vaccine. We note that age was associated with a lower 


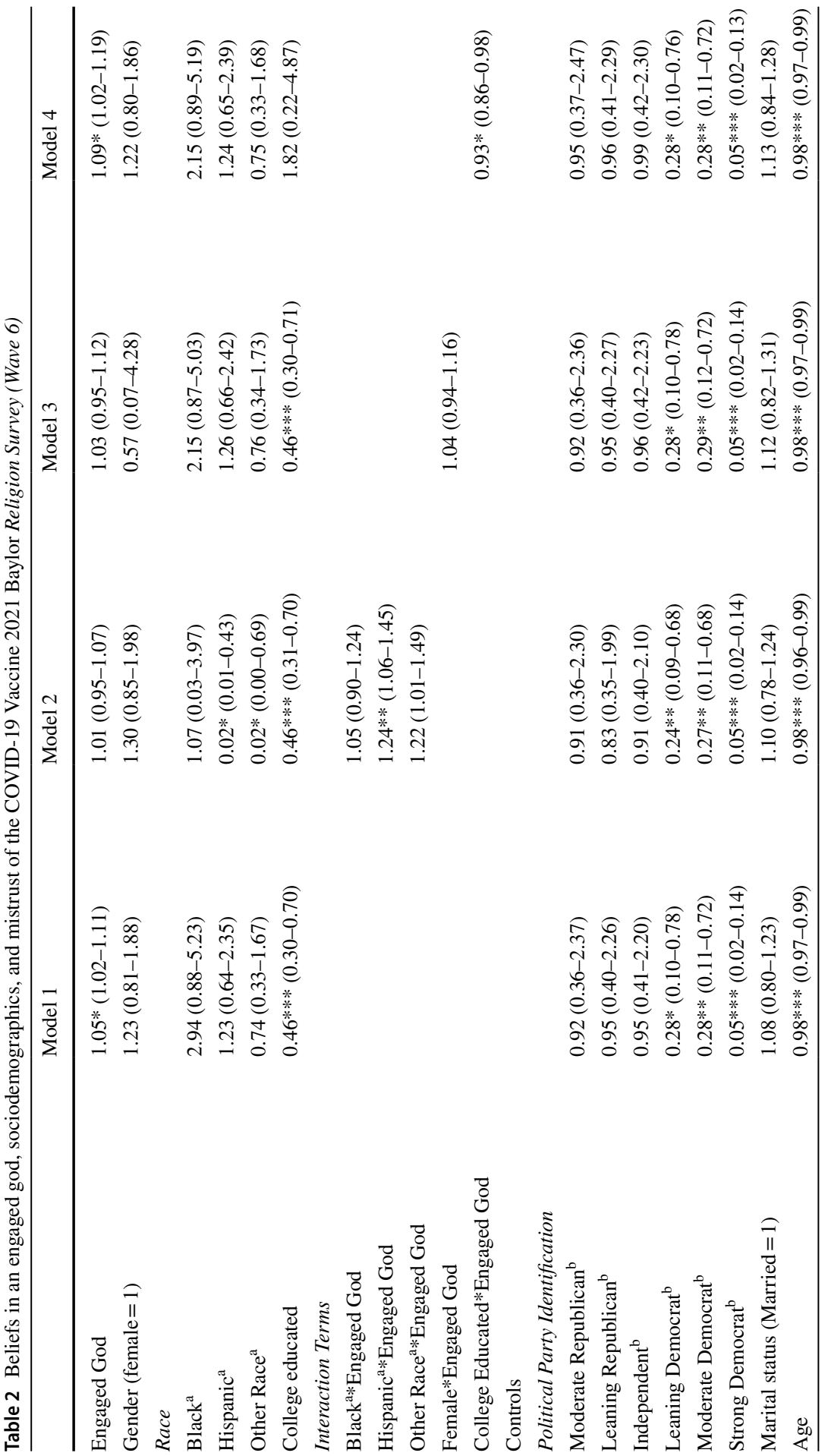


|nd

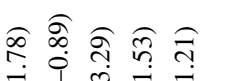

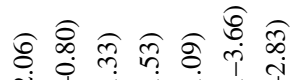

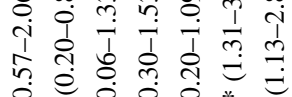

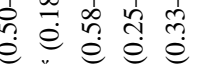

e

e 巳

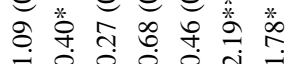

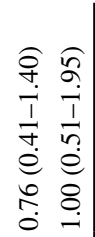

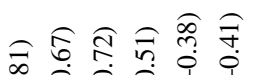

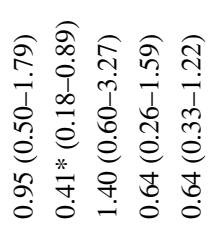

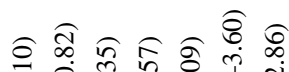

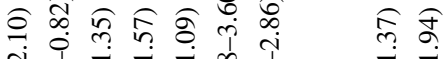

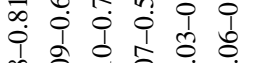

ก T ग T

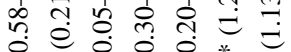

e

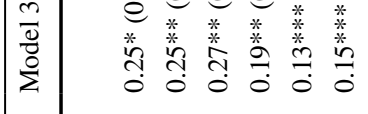

=

곡ำ

è

$0 \rightarrow 00$

$\stackrel{8}{\circ} \underset{0}{\stackrel{2}{0}}$

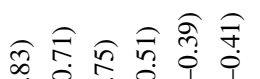

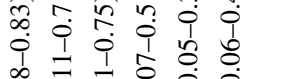

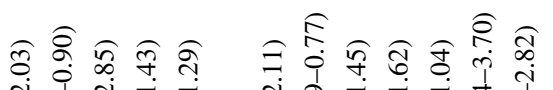

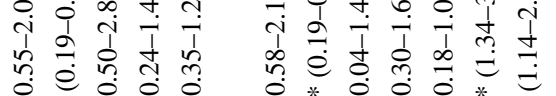

e * e e e

范

=

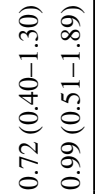

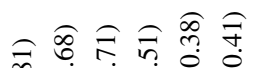

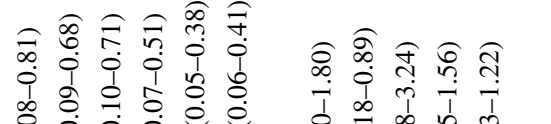

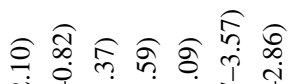

तi $=1 \frac{1}{1}$ के

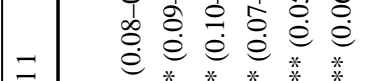

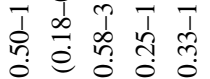

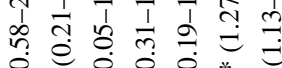

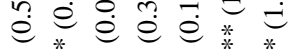

先 先

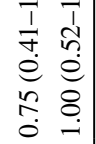

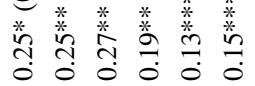

$e+e e$

ڤ.

- $0000 \%$

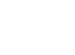
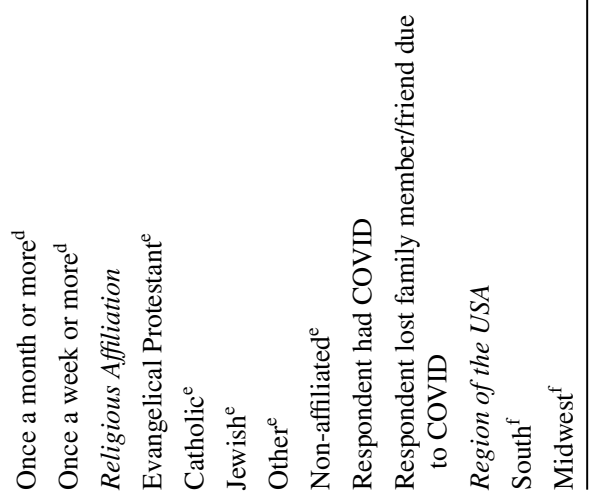


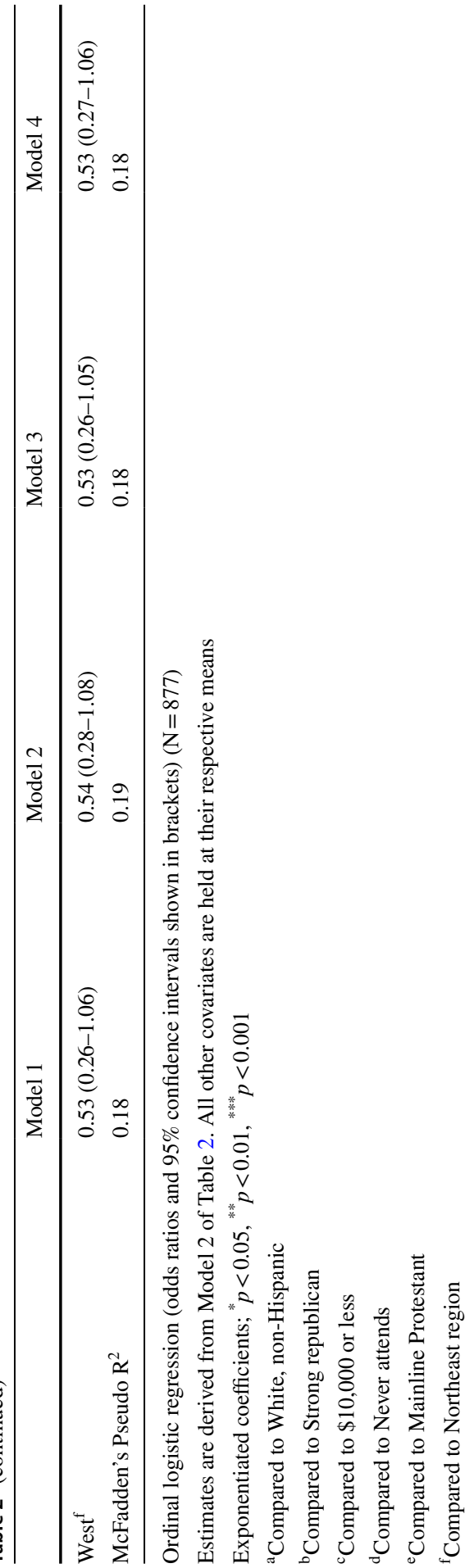




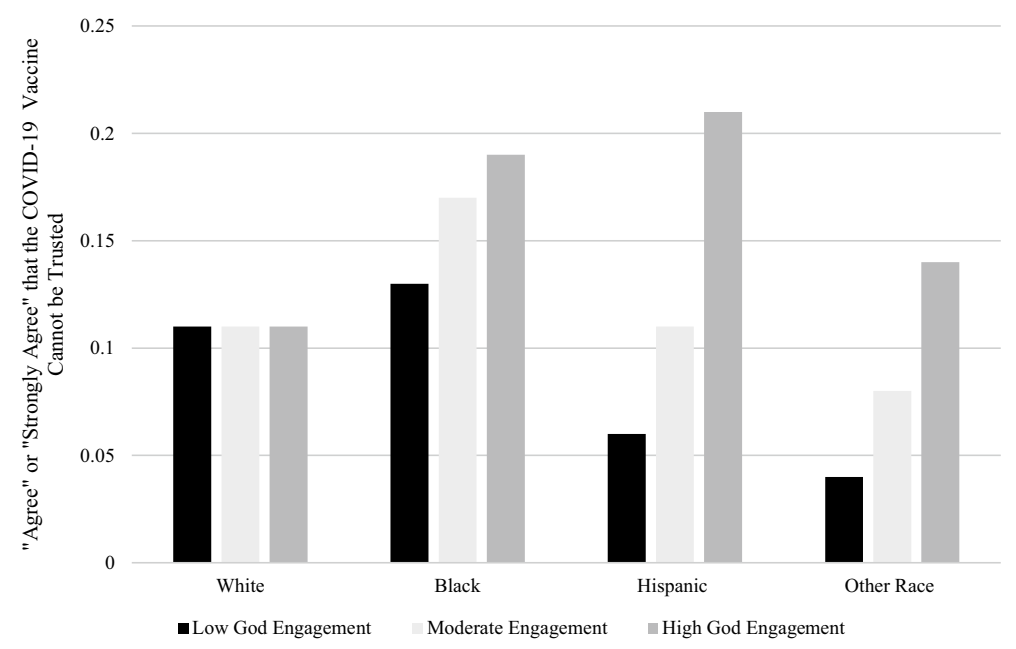

Fig. 1 God Engagement and Trust in COVID-19 Vaccine: The Moderating Role of Race Estimates are derived from Model 2 of Table 2. All other covariates are held at their respective means

likelihood of mistrusting the vaccine $(\mathrm{OR}=0.98, p<0.001)$ as were sequentially higher levels of household income and political party identification, where Democrats were less likely to mistrust the vaccine relative to Republicans. There were no consistent patterns of religious attendance holding differential likelihoods of mistrusting the vaccine. As for religious denominational affiliation, Catholics seemed to have a lower likelihood of mistrusting the vaccine $(\mathrm{OR}=0.41$, $p<0.05)$, however, Evangelical Protestants were no more likely than Mainline Protestants to mistrust the vaccine (a result which remained non-significant even with the exclusion of political party identification from ancillary models, given the tendency for Evangelical Protestants to identify as Republican). Region of residence in the USA also bore no association with vaccine mistrust.

One other finding of interest from Model 1 was that respondents who either themselves had COVID-19 in the past year or who lost a close family member/friend due to the virus were more likely to mistrust the vaccine $(\mathrm{OR}=2.12$, $p<0.01$, and $\mathrm{OR}=1.80, p<0.05$ ), respectively. Though this finding may seem to go against what might be expected, Piltsch-Loeb and colleagues (2021) found a similar result in their analysis predicting COVID-19 vaccine hesitancy.

Having established these baseline associations, Models 2-4 of Table 2 serve as tests of Hypotheses 2, 3, 4. In Model 2, we test the multiplicative effect of race*beliefs in an engaged God. We observe one significant interaction term there, between beliefs in an engaged God and Hispanic $(\mathrm{OR}=1.24, p<0.01)$. To visualize this association, Fig. 1 shows the predicted probability of strongly agreeing/agreeing that the COVID-19 vaccine cannot be trusted across three levels of beliefs in an engaged God: one standard deviation below the sample mean ("Low God Engagement"), at the sample mean ("Moderate Engagement"), and at 


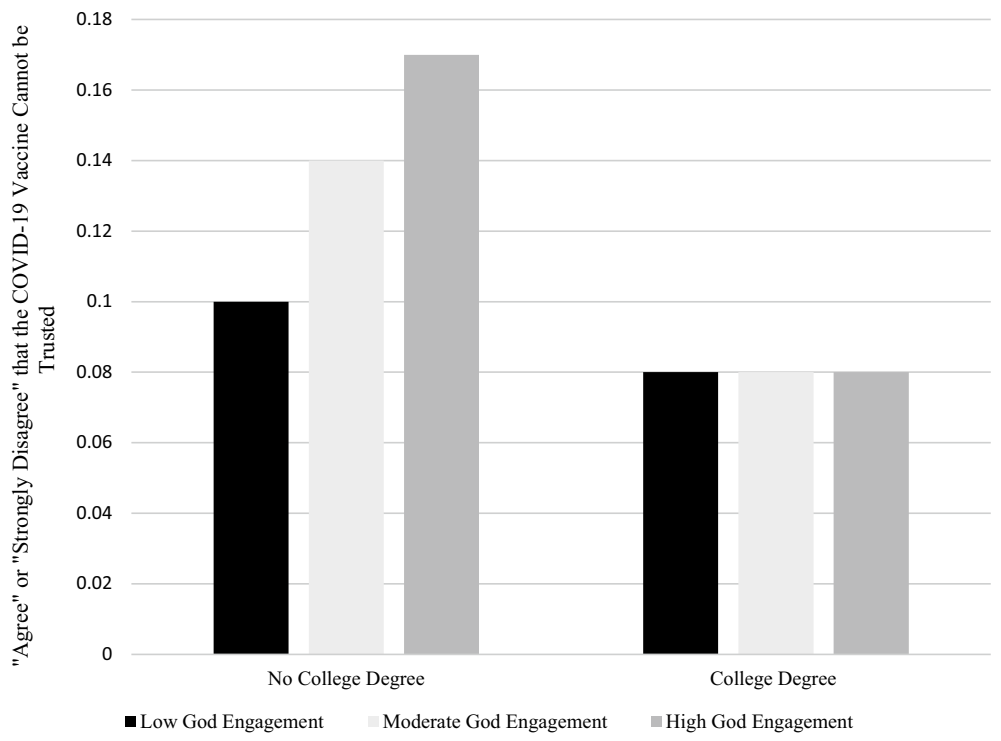

Fig. 2 God Engagement and Trust in the COVID-19 Vaccine: The Moderating Role of Education Estimates are derived from Model 4 of Table 2. All other covariates are held at their respective means

one standard deviation above the sample mean ("High God Engagement"), holding all other covariates at their respective means.

As shown in Fig. 1 in the third set of bars, Hispanics with high beliefs in God engagement had a $21 \%$ change of mistrusting the vaccine, compared to only $11 \%$ at the mean levels of God engagement beliefs and $6 \%$ at low beliefs in God engagement. Therefore, there was a $15 \%$ difference in probability in mistrusting the vaccine for Hispanics with low versus high beliefs in an engaged God. It is also clear from Fig. 1 that a similar pattern does not emerge for African American respondents or for "Other Race" respondents, findings which we return to in the discussion section. Thus, we see support only for Hypothesis $2 \mathrm{~b}$ : the relationship between beliefs in an engaged God and mistrust in the COVID-19 vaccine is more pronounced for Hispanic Americans in our sample.

Model 3 of Table 2 serves as a test of Hypothesis 3, which posited that gender may condition the relationship between beliefs in an engaged God and mistrust of the vaccine. A null interaction term between gender and beliefs in an engaged God $(\mathrm{OR}=1.04, p>0.05)$ does not provide support for this hypothesis, however.

Finally, Model 4 of Table 2 tests the statistical interaction between college education and beliefs in an engaged God. This interaction term was found to be statistically significant $(\mathrm{OR}=0.93, p<0.05)$. Figure 2 shows the predicted probabilities of strongly agreeing/agreeing that the vaccine can be trusted across levels of beliefs in God engagement in the same fashion as in Fig. 1. As depicted in Fig. 2, among respondents with a college degree, beliefs in God engagement did little to alter their predicted probability of strongly agreeing/agreeing that the 
vaccine could be trusted, as respondents across levels of beliefs in God engagement reported an $8 \%$ chance of falling into this category. The narrative is much different for those without a college education, as those holding high beliefs in God engagement had a $17 \%$ chance of reporting vaccine mistrust, compared to only $14 \%$ among those with mean levels of belief in God engagement, and $10 \%$ for those with low level of belief in God engagement. Therefore, we find support for Hypothesis 4: the relationship between beliefs in an engaged God and mistrust of the COVID-19 vaccine are stronger for those with lower levels of education.

\section{Supplemental Analyses}

The 2021 Baylor Religion Survey measured attitudes of trust in the COVID-19 vaccine, not actual vaccine uptake. Ancillary analyses used data from the 2021 Crime, Health, and Politics Survey (CHAPS) which allowed us to consider vaccine uptake with a similar (though distinct) variable related to God's involvement in human life, beliefs in divine control. CHAPS is based on a national probability sample of 1,771 community-dwelling adults aged 18 and over living the USA. Respondents were sampled from the National Opinion Research Center's (NORC) AmeriSpeak (C) panel, which is representative of households from all 50 states and the District of Columbia. After removing cases missing on variables included in this analysis, we are left with a final analytic sample of 1,708 cases.

As a measure of COVID-19 vaccine uptake, respondents were asked, "Have you been vaccinated for the coronavirus?" Response options were $1=$ "Yes," $2=$ "No, but I am planning to be vaccinated," $3=$ "No, and I do not plan to be vaccinated," and $4=$ "No, and I am undecided about getting a vaccine." We combined response categories 1 and 2 to indicate "Yes" to COVID-19 vaccine uptake, since we took intent to be vaccinated as an assumption that a person would eventually get the vaccine should they become eligible, and responses 3 and 4 to create a binary variable of vaccine uptake. According to this coding scheme, $70.98 \%$ of the sample had either received or were planning to receive the vaccine (1), compared to $29.02 \%$ who were not planning to or were undecided (0).

Though belief in an engaged God were not available in CHAPS, a conceptual neighbor, beliefs in divine control, were. Three survey items were designed to measure perceptions of divine control (Schieman et al., 2005, 2006). Respondents were asked to respond to the following prompts: (1) "God has decided what my life shall be," (2) "I decide to do without relying on God for help," (reversecoded) and (3) "I depend on God for help and guidance." Response options were from $1=$ Strongly disagree to $5=$ "Strongly agree." These three items were averaged to form a scale, where higher scores indicate stronger beliefs in divine control (Cronbach's alpha $=0.87$ ). Respondents had a mean divine control score of $3.15(\mathrm{SD}=0.62)$.

Appendix presents results from a binary logistic regression model showing the association between divine control beliefs, adjusting for several standard demographic characteristics (age, marital status, income, education, employment, 
political party identification, region of the country) and religiosity (religious affiliation, attendance, religious importance). Divine control beliefs were associated with a decreased likelihood of having had or planning to have the COVID-19 vaccine $(\mathrm{OR}=0.68, p<0.001)$. Respondents with divine control beliefs one standard deviation above the mean had only a $66 \%$ chance of being vaccinated or planning to take the vaccine, compared to a $78 \%$ chance for those with low divine control beliefs (one standard deviation below the mean). These analyses therefore suggest that attributing some causal influence to God in one's life is associated with greater vaccine mistrust (main results) as well as lower vaccine uptake (supplemental analyses).

\section{Discussion}

The chief goal of the current study was to assess whether one form of religious belief-the belief in an engaged, involved God who plays a causal role in human life and worldly affairs-was associated with greater mistrust of the COVID19 vaccine, and whether this association was further contingent on sociodemographic characteristics. This research objective fits in squarely with recent literature on religion and health, which has suggested a bifurcation of positive and negative implications to health from religious belief and involvement. On the one hand, a large body of work suggests that religiosity has a favorable impact on coping with adversity, including stress related to the current pandemic (Counted et al., 2020), and therefore should be health promoting (see Koenig et al., 2012; Page et al., 2020 for reviews). On the other hand, however, religiosity has been shown to be associated with a skepticism of science and a lack of analytical thinking and problem-solving skills (Evans, 2013; Gervais \& Norenzayan, 2012), competencies of utmost importance for reasonably responding to the pandemic and protecting oneself and others through the COVID-19 vaccine. Beliefs in an influential God who is seen as the ultimate protector and arbiter of life and death might make individuals less prone to take agentic action by getting the COVID19 vaccine.

The first key finding of our study was that beliefs in an engaged God were indeed associated with greater mistrust in the COVID-19 vaccine. This result is compatible with recent research showing that religiosity, broadly defined, is negatively related with trust in scientific research related to COVID-19 and lower COVID-19 vaccination intention (Olagoke et al., 2021; Plohl \& Musil, 2021). We would argue that there is an important distinction to be made between trust in scientific research and vaccine intention and mistrust of the vaccine. Though the same underlying processes may be at play (e.g., higher levels of religious belief portend scientific mistrust), the introduction of mistrust in the vaccine is an important contribution to this body of work. Mistrust of the vaccine could signal not only hesitancy or resistance to get vaccinated but also fundamental mistrust in science, which could extend to all scientific evidence surrounding the epidemiology of the coronavirus. Thus, we suspect that mistrust of the vaccine will capture 
more general attitudes toward the pandemic and mitigation efforts, as well as measuring how much a person trusts in a specific health behavior.

While we did not have the measures available in Wave 6 of the Baylor Religion Survey to test whether beliefs in an engaged God were associated with an external locus of health control, we suspect this is the process that underlies why those believing in an engaged God report greater mistrust. Previous research has found this to be a significant mediating pathway between religiosity and intentions to vaccinate (Olagoke et al., 2021). In general, the process of "spiritual surrender" (turning one's life over to God) may be constructive insofar as it helps individuals confront the challenges they face and successfully executing the responsibilities in their life. Therefore, it would be an oversimplification to conclude that externalizing health beliefs are uniformly harmful. However, beliefs in an engaged God may provide the impetus people need to distrust the vaccine and decrease one's sense of internal control over health, which might inhibit vaccinating oneself against COVID-19. Strong beliefs in an engaged God may lead religious adherents to believe that God is "bigger" than the virus (Sinding-Bentzen, 2019), and that His protection is considerably more powerful and efficacious than any scientific creation developed by humankind. In other words, by shifting responsibility for one's health outwards to a powerful, engaged divine being, believers may be lifting some of the onus off themselves for their health-related decisions.

There were also two important sociodemographic contingencies of this main association between beliefs in an engaged God and COVID-19 vaccine mistrust. First, this association was amplified for Hispanic Americans, as those holding strong beliefs in an engaged God were nearly $20 \%$ more likely to mistrust the vaccine than those holding weak beliefs in an engaged God. Though considerably less attention has been dedicated to understanding religion and health among Hispanic Americans compared to African Americans, there could be a few reasons underlying these findings that we observed. First, Hispanics, more than any other racial group in the USA, tend to hold fast to the conviction that God will find a way to assist them if they show sufficient faith (Schieman \& Jung, 2012). In addition to their propensity to have an external locus of health control (Chavez et al., 1997), strong beliefs in the causal influence of God in daily life may fuel mistrust in the vaccine, especially when combined with the fact that Hispanics are the group least likely to have medical insurance and occupy a marginalized status within the medical system because of language barriers. Second, on a more technical level, our analytic sample was comprised of more than $15 \%$ Hispanics, thereby giving us sufficient statistical power to detect these moderation patterns compared to African Americans, who only comprised $11 \%$ of our analytic sample.

A significant null finding of the current study is that beliefs in an engaged God did not predict different probabilities of mistrusting the vaccine for African Americans. This is somewhat surprising, given the propensity of Blacks to distrust both the medical system (Allen \& de Jesus et al., 2012; Galbraith et al., 2016;) and vaccines (Webb et al., 2018; Whitehead \& Perry, 2020) more than their White counterparts, as well as their greater likelihood of believing in an engaged, all-powerful God (Lincoln \& Mamiya, 1990). It is notable that we did not observe in main effects models that being Black was associated with COVID-19 vaccine mistrust; we speculate that 
this is because nearly $50 \%$ of Blacks in our analytic sample had a college education compared to less than $30 \%$ of Hispanics. As we saw, education was strongly related to lower mistrust of the vaccine across all models. Therefore, it is possible that the effect of education overrides the effect of race and beliefs in an engaged God. However, given that this is the first study to assess how a specific religious belief influences mistrust of the COVID-19 vaccine, more research is needed before definitive conclusions can be drawn.

We also found no evidence that women were more likely to mistrust the COVID19 vaccine if they held beliefs in an engaged God. This is not entirely surprising, given the mixed body of evidence on gender on vaccine intentions and uptake (Piltch-Loeb et al., 2021) and the limited available evidence on gender and beliefs in God's causal influence over daily life (Schieman, 2010). We did, however, document a second sociodemographic contingency, whereby beliefs in an engaged God were associated with greater mistrust in the vaccine among those with less than a college education. This result is consistent with the tenets of deprivation-compensation theory, which posit that individuals with fewer SES resources tend to exhibit greater beliefs in divine engagement and involvement and hold external loci of control (Drapeer \& Baker, 2011). Those with lower levels of education also tend to report greater distrust in science, perhaps because of a lack of familiarity with scientific procedures (Evans, 2011). Altogether, a lack of faith in science, coupled with beliefs in an engaged God who is in control of daily life and one's health, appear to promote high levels of mistrust in the COVID-19 vaccine among Americans with less than a college education. Deferring control over whether one gets infected with the coronavirus, and the severity of possible symptoms, to God may be an appealing strategy for the lower educated, who already tend to display a hesitancy to be vaccinated.

On the other hand, higher education is often associated with a critical, scientific worldview that may be at odds with religious doctrines and beliefs (Schwadel, 2011). Well-educated individuals also tend to have a higher sense of personal control, attributing outcomes like health to internal sources and their own efforts rather than external sources such as God (Schieman \& Plickert, 2008). Viewed in this way, education may discount the idea of divine influence in daily life (and especially over the coronavirus) because it promotes a worldview centered on critical thought and personal agency. Therefore, equipped with the statistical evidence of the safety and efficacy of the COVID-19 vaccine, those with higher education choose to get vaccinated irrespective of how engaged they believe God is in daily life.

Taken together, the results from this study (as well as the implications that follow from them) suggest that religious beliefs may bear a complex and multifaceted relationship to health. We recognize that the relationship between religiosity and mistrust in the COVID-19 vaccine cannot be fully examined by assessing only one dimension of religious belief. However, we elected to focus on beliefs in an engaged God to provide a starting point for future research to build on. We argue that, perhaps more than any other religious cognition or belief, beliefs in an engaged God may promote a distrust of science, reduce motivation to engage in positive health behaviors (such as vaccination), and allow believers to derive comfort and strength by placing control over one's life in the hands of a loving, involved deity. Though it would be premature to conclude that beliefs in an engaged God are unequivocally 
harmful for health and health care management, it is evident that they may portend a lower likelihood of vaccinating oneself against the coronavirus despite the widespread availability of several vaccines in the USA.

\section{Limitations and Future Directions}

Several limitations of the current study should be kept in mind. First, the use of cross-sectional data makes it impossible to establish causality and requires a careful interpretation of results. It is possible that those who are more likely to distrust science and the vaccine are more prone to join religious groups which may confirm their anti-science bias. Moreover, the ongoing nature of the COVID-19 pandemic means that efforts should be made to collect data at multiple time points to assess how beliefs in an engaged God, or other forms of religiosity, influence the mistrust of the vaccine. This is especially crucial given that BRS data were collected between January and March 2021, where there was less information on the efficacy of vaccines and when vaccines were not widely available to all Americans regardless of age or pre-existing health conditions. Vaccine mistrust may change over time as individual's views shift in response to new information or as additional waves of outbreaks of the virus occurred in some areas of the USA.

Second, this study also relied on self-reported measured of mistrust in the COVID-19 vaccine. Such measures are always susceptible to self-presentation biases. We suspect, however, that any bias in this regard would lead our results to be conservative in nature, as respondents would be more likely to "disagree" that the vaccine could not be trusted given widespread encouragement to get vaccinated by government and health officials.

Third, we were unable to account for other variables that are likely associated with (mis)trust in the vaccine. Other commonly studied factors associated with vaccine mistrust include a history of not receiving the influenza vaccination, a lower self-perceived risk of contracting or having serious health complications from COVID-19, and having concerns about the safety of the vaccines given underlying health conditions (e.g., the tendency to have blood clots). We also note that the BRS-6 only included respondents who were over 18 years of age. If their parents have a negative disposition to the vaccine, this could prevent them from getting it, if a vaccine is authorized for those under the age of 12 .

Our study offers a snapshot of attitudes toward vaccination in the USA just prior to when all adults became eligible for the vaccine. Devoting attention to population profiles of vaccine mistrust, as well as how beliefs in an engaged God factor in, can aid public health officials in potentially targeting new strategies for increasing vaccine uptake. However, such efforts should not come from the secular world alone, but also from inside religious communities, integrated with religious doctrines and worldviews. One profitable strategy might be to have religious leaders educating their members on their need to take responsibility for their health even as they ascribe much control over their life to God. For instance, drawing on scriptural themes, such as individuals collaborating with God to solve problems rather than ceding complete control (Krause, 2005), can provide a faith-based justification for 
shifting from an external to an internal loci of health control and taking steps to protect oneself against the virus, especially for racial minorities and those with a low education. Religious leaders may thus be well poised to use their formal or informal platforms to communicate messages regarding the importance of getting fully vaccinated against COVID-19.

Although there is strong evidence that religious involvement generally has positive effects on individual health outcomes, at least in the American population, there is also a growing literature on the situations and particular groups for which this effect might be reversed (Ellison \& Lee, 2010). Elaborating on the "dark side" of religion and health is therefore necessary before we can fully harness the healthpromoting tendencies of religious belief and involvement. Distrust in the COVID-19 vaccine remains a fairly prevalent problem in the USA, and Hispanic Americans and those with less than a college education were particularly susceptible to vaccine mistrust if they also believed in an engaged God. As we have shown, understanding the importance of religious beliefs alongside sociodemographic characteristics in attitudes toward the COVID-19 vaccine represents a crucial step in identifying what may hinder vaccine uptake and ultimately delay reaching herd immunity.

\section{Appendix}

Coefficients from Binary Logistic Regression Models Predicting Vaccine Uptake by Divine Control, CHAPS (N=1,708) (Odds Ratios and 95\% Confidence Intervals Shown).

Model 1

Focal independent variable

Divine control

$0.68 * *(0.54-0.87)$

Control variables

Age Categories

30-44 years $^{\mathrm{a}}$

$0.63 *(0.42-0.95)$

45-59 years $^{\mathrm{a}}$

$1.31(0.83-2.07)$

60 years or older ${ }^{\mathrm{a}}$

$3.30 * * *(2.05-5.32)$

Race

Black, non-Hispanic ${ }^{\mathrm{b}}$

$0.43 * * *(0.28-0.69)$

Hispanic $^{\mathrm{b}}$

$0.91(0.64-1.32)$

Other Race ${ }^{b}$

$0.97(0.54-1.75)$

Gender

Female $^{\mathrm{c}}$

$0.96(0.75-1.25)$

Educational Attainment

HS graduate or equivalent ${ }^{\mathrm{d}}$

$1.08(0.56-2.10)$

Vocational/tech school/some college/associates degree ${ }^{\mathrm{d}}$

$1.25(0.66-2.35)$

Bachelor's degree $^{\mathrm{d}}$

$2.12 *(1.07-4.19)$

Post-grad study/professional Degree ${ }^{\mathrm{d}}$

$2.89 * *(1.35-6.18)$

Income 


\begin{tabular}{|c|c|}
\hline & Model 1 \\
\hline$\$ 30,000-\$ 60,000^{\mathrm{e}}$ & $1.04(0.74-1.46)$ \\
\hline$\$ 60,000$ to under $\$ 100,000^{\mathrm{e}}$ & $1.72 * *(1.18-2.50)$ \\
\hline$\$ 100,000$ or more ${ }^{e}$ & $1.83 * *(1.19-2.83)$ \\
\hline Unemployed due to COVID-19 & $0.62 * *(0.46-0.84)$ \\
\hline \multicolumn{2}{|l|}{ Political Party Identification } \\
\hline Moderate Democrat ${ }^{f}$ & $0.73(0.44-1.22)$ \\
\hline Lean Democrat ${ }^{\mathrm{f}}$ & $0.61(0.33-1.12)$ \\
\hline Don't Lean/ Independent/None ${ }^{f}$ & $0.26 * * *(0.16-0.43)$ \\
\hline Lean Republican ${ }^{\mathrm{f}}$ & $0.10 * * *(0.06-0.16)$ \\
\hline Moderate Republican ${ }^{\mathrm{f}}$ & $0.15^{* * *}(0.09-0.26)$ \\
\hline Strong Republican ${ }^{\mathrm{f}}$ & $0.09 * * *(0.05-0.14)$ \\
\hline \multicolumn{2}{|l|}{ Marital status } \\
\hline Widowed $^{\mathrm{g}}$ & $1.12(0.56-2.27)$ \\
\hline Divorced $^{\mathrm{g}}$ & $0.94(0.61-1.44)$ \\
\hline Separated $^{\mathrm{g}}$ & $1.95(0.91-4.15)$ \\
\hline Never married ${ }^{\mathrm{g}}$ & $1.09(0.76-1.58)$ \\
\hline Living with partner ${ }^{\mathrm{g}}$ & $0.76(0.44-1.31)$ \\
\hline \multicolumn{2}{|l|}{ Region of USA } \\
\hline Midwest $^{\mathrm{h}}$ & $0.97(0.64-1.48)$ \\
\hline South $^{\mathrm{h}}$ & $0.68(0.46-1.03)$ \\
\hline West $^{\mathrm{h}}$ & $0.88(0.57-1.36)$ \\
\hline \multicolumn{2}{|l|}{ Religious controls } \\
\hline Weekly attendance ${ }^{\mathrm{i}}$ & $1.26(0.97-1.63)$ \\
\hline High religious importance $^{j}$ & $0.78(0.56-1.09)$ \\
\hline \multicolumn{2}{|l|}{ Religious Affiliation } \\
\hline Mainline Protestant ${ }^{\mathrm{k}}$ & $1.52(1.00-2.32)$ \\
\hline Catholic $^{\mathrm{k}}$ & $1.53^{*}(1.03-2.26)$ \\
\hline Other Christian $^{\mathrm{k}}$ & $1.36(0.91-2.04)$ \\
\hline Other Religion $^{\mathrm{k}}$ & $1.74(0.82-3.69)$ \\
\hline No religion ${ }^{\mathrm{k}}$ & $1.39(0.91-2.12)$ \\
\hline
\end{tabular}

$* * * p<0.001, * * p<0.01, * p<0.05$

${ }^{\text {a }}$ compared to $18-29$ years

b compared to White, non-Hispanic

${ }^{c}$ compared to Male

${ }^{\mathrm{d}}$ compared to Less than high school

e compared to $\$ 30,000$ or less

${ }^{\mathrm{f}}$ compared to Strong Democrat

${ }^{\mathrm{g}}$ compared to Married

${ }^{\mathrm{h}}$ compared to Northeast region compared to Less than weekly attendance

${ }^{\mathrm{i}}$ compared to Moderate/Low religious importance

${ }^{\mathrm{k}}$ compared to Conservative Protestant. 
Acknowledgements We thank the editor and anonymous reviewers for providing helpful feedback on an earlier version of this manuscript.

Funding None.

\section{Declarations}

Conflict of interest The authors declare that they have no conflict of interest.

\section{References}

Allen, J. D., De Jesus, M., Mars, D., Tom, L., Cloutier, L., \& Shelton, R. C. (2012). Decision-making about the HPV vaccine among ethnically diverse parents: Implications for health communications. Journal of Oncology. https://doi.org/10.1155/2012/401979

Amit Aharon, A., Nehama, H., Rishpon, S., \& Baron-Epel, O. (2018). A path analysis model suggesting the association between health locus of control and compliance with childhood vaccinations. Human Vaccines \& Immunotherapeutics, 14(7), 1618-1625. https://doi.org/10.1080/21645515. 2018.1471305

Bogart, L. M., Ojikutu, B. O., Tyagi, K., Klein, D. J., Mutchler, M. G., Dong, L., \& Kellman, S. (2021). COVID-19 related medical mistrust, health impacts, and potential vaccine hesitancy among Black Americans living with HIV. Journal of Acquired Immune Deficiency Syndromes, 86(2), 200-207. https://doi.org/10.1097/QAI.0000000000002570

Bonhag, R., \& Upenieks, L. (2021). Mattering to god and to the congregation: Gendered effects in mattering as a mechanism between religiosity and mental health. Journal for the Scientific Study of Religion. https://doi.org/10.1111/jssr.12753

Boyd, J. M., \& Wilcox, S. (2020). Examining the relationship between health locus of control and god locus of health control: is god an internal or external source? Journal of Health Psychology, 25(7), 931-940. https://doi.org/10.1177/1359105317739099

Burdette, A. M., Gordon-Jokinen, H., \& Hill, T. D. (2014). Social determinants of HPV vaccination delay rationales: Evidence from the 2011 National Immunization Survey-Teen. Preventive Medicine Reports, 1, 21-26. https://doi.org/10.1016/j.pmedr.2014.09.003

Cacciatore, M. A., Browning, N., Scheufele, D. A., Brossard, D., Xenos, M. A., \& Corley, E. A. (2018). Opposing ends of the spectrum: Exploring trust in scientific and religious authorities. Public Understanding of Science, 27(1), 11-28. https://doi.org/10.1177/0963662516661090

CDC. (2021). COVID-19: SARS-CoV-2 variant classifications and definitions. Atlanta, GA: US Department of Health and Human Services, CDC; 2021. Accessed August 25, 2021. https:// www.cdc.gov/coronavirus/2019-ncov/cases-updates/variant-surveillance/variant-info.html

Chavez, L. R., Hubbell, F. A., Mishra, S. I., \& Valdez, R. B. (1997). The influence of fatalism on selfreported use of Papanicolaou smears. American Journal of Preventive Medicine, 13, 418-424. https://doi.org/10.1016/S0749-3797(18)30134-X

Counted, V., Pargament, K. I., Bechara, A. O., Joynt, S., \& Cowden, R. G. (2020). Hope and well-being in vulnerable contexts during the COVID-19 pandemic: does religious coping matter? The Journal of Positive Psychology. https://doi.org/10.1080/17439760.2020.1832247

Debnam, K. J., Holt, C. L., Clark, E. M., Roth, D. L., Foushee, H. R., Crowther, M., \& Southward, P. L. (2012). Spiritual health locus of control and health behaviors in African Americans. American Journal of Health Behavior, 36(3), 360-372. https://doi.org/10.5993/AJHB.36.3.7

DeFranza, D., Lindow, M., Harrison, K., Mishra, A., \& Mishra, H. (2020). Religion and reactance to COVID-19 mitigation guidelines. American Psychologist. https://doi.org/10.1037/amp0000717

DeRoo, S. S., Pudalov, N. J., \& Fu, L. Y. (2020). Planning for a COVID-19 vaccination program. JAMA, 323(24), 2458-2459. https://doi.org/10.1001/jama.2020.8711

Draper, S., \& Baker, J. O. (2011). Angelic belief as American folk religion. Sociological Forum, 26(3), 623-643. https://doi.org/10.1111/j.1573-7861.2011.01265.x

Ecklund, E. H., \& Scheitle, C. P. (2017). Religion vs science. What religious people really think. Oxford University Press. 
Edwards, B., Biddle, N., Gray, M., \& Sollis, K. (2021). COVID-19 vaccine hesitancy and resistance: Correlates in a nationally representative longitudinal survey of the Australian population. PLoS ONE, 16(3), e0248892. https://doi.org/10.1371/journal.pone.0248892

Egede, L. E., \& Bonadonna, R. J. (2003). Diabetes self-management in African Americans: An exploration of the role of fatalism. The Diabetes Educator, 29(1), 105-115. https://doi.org/10.1177/ 014572170302900115

Ellison, C. G., \& Lee, J. (2010). Spiritual struggles and psychological distress: Is there a dark side of religion? Social Indicators Research, 98(3), 501-517. https://doi.org/10.1007/ s11205-009-9553-3

Ellison, C. G., \& Musick, M. A. (1995). Conservative Protestantism and public opinion toward science. Review of Religious Research, 36(3), 245-262. https://doi.org/10.2307/3511533

Espinosa, L. (2011). Pipelines and pathways: Women of color in undergraduate STEM majors and the college experiences that contribute to persistence. Harvard Educational Review, 81(2), 209-241.

Evans, J. H. (2011). Epistemological and moral conflict between religion and science. Journal for the Scientific Study of Religion, 50(4), 707-727. https://doi.org/10.1111/j.1468-5906.2011.01603.x

Evans, J. H. (2013). The growing social and moral conflict between conservative Protestantism and science. Journal for the Scientific Study of Religion, 52(2), 368-385. https://doi.org/10.1111/jssr.12022

Evans, J. H. (2018). Morals not knowledge. University of California Press.

Evans, J. H., \& Evans, M. S. (2008). Religion and science: Beyond the epistemological conflict narrative. Annual Review of Sociology, 34, 87-105. https://doi.org/10.1146/annurev.soc.34.040507.134702

Evans, J. H., \& Feng, J. (2013). Conservative Protestantism and skepticism of scientists studying climate change. Climatic Change, 121(4), 595-608. https://doi.org/10.1007/s 10584-013-0946-6

Evans, J. H., \& Hargittai, E. (2020). Who doesn't trust Fauci? The public's belief in the expertise and shared values of scientists in the COVID-19 pandemic. Socius, 6, 2378023120947337. https://doi. org/10.1177/2378023120947337

Flórez, K. R., Aguirre, A. N., Viladrich, A., Céspedes, A., De La Cruz, A. A., \& Abraído-Lanza, A. F. (2009). Fatalism or destiny? A qualitative study and interpretative framework on Dominican women's breast cancer beliefs. Journal of Immigrant and Minority Health, 11(4), 291-301. https://doi. org/10.1007/s 10903-008-9118-6

Franklin, M. D., Schlundt, D. G., McClellan, L. H., Kinebrew, T., Sheats, J., Belue, R., \& Hargreaves, M. (2007). Religious fatalism and its association with health behaviors and outcomes. American Journal of Health Behavior, 31(6), 563-572. https://doi.org/10.5993/AJHB.31.6.1

Franklin, M. D., Schlundt, D. G., \& Wallston, K. A. (2008). Development and validation of a religious health fatalism measure for the African-American faith community. Journal of Health Psychology, 13(3), 323-335. https://doi.org/10.1177/1359105307088137

Froese, P., \& Bader, C. (2010). America's Four Gods: What We Say about God-and What That Says about Us. Oxford University Press.

Galbraith, K. V., Lechuga, J., Jenerette, C. M., Moore, L. A. D., Palmer, M. H., \& Hamilton, J. B. (2016). Parental acceptance and uptake of the HPV vaccine among African-Americans and Latinos in the United States: A literature review. Social Science \& Medicine, 159, 116-126. https://doi.org/10. 1016/j.socscimed.2016.04.028

Gauchat, G. (2012). Politicization of science in the public sphere: A study of public trust in the United States, 1974 to 2010. American Sociological Review, 77(2), 167-187. https://doi.org/10.1177/00031 22412438225

Gauchat, G. (2015). The political context of science in the United States: Public acceptance of evidencebased policy and science funding. Social Forces, 94(2), 723-746. https://doi.org/10.1093/sf/sov040

Gervais, W. M., \& Norenzayan, A. (2012). Analytic thinking promotes religious disbelief. Science, 336(6080), 493-496. https://doi.org/10.1126/science.1215647

Hayward, R. D., Krause, N., \& Pargament, K. (2017). The prevalence and antecedents of religious beliefs about health control in the US population: Variations by race and religious background. Journal of Religion and Health, 56(6), 2194-2211. https://doi.org/10.1007/s10943-017-0391-3

Johnson, K. A., Baraldi, A. N., Moon, J. W., Okun, M. A., \& Cohen, A. B. (2021). Faith and science mindsets as predictors of COVID-19 concern: A three-wave longitudinal study. Journal of Experimental Social Psychology, 96, 104186. https://doi.org/10.1016/j.jesp.2021.104186

Jung, J. H. (2020). Belief in supernatural evil and mental health: Do secure attachment to god and gender matter? Journal for the Scientific Study of Religion, 59(1), 141-160. https://doi.org/10.1111/jssr. 12645 
Khubchandani, J., Sharma, S., Price, J. H., Wiblishauser, M. J., Sharma, M., \& Webb, F. J. (2021). COVID-19 vaccination hesitancy in the United States: A rapid national assessment. Journal of Community Health, 46(2), 270-277. https://doi.org/10.1007/s10900-020-00958-x

Kitchens, M. B., \& Phillips, R. E. (2018). A curvilinear relationship between clear beliefs about god and self-concept clarity. Psychology of Religion and Spirituality. https://doi.org/10.1037/rel0000181. Advance online publication

Koenig, H., Koenig, H. G., King, D., \& Carson, V. B. (2012). Handbook of religion and health. Oxford University Press.

Krause, N. (2005). God-mediated control and psychological well-being in late life. Research on Aging, 27(2), 136-164. https://doi.org/10.1177/0164027504270475

Lehman, D., \& Sherkat, D. E. (2018). Measuring religious identification in the United States. Journal for the Scientific Study of Religion, 57(4), 779-794. https://doi.org/10.1111/jssr.12543

Lincoln, C. E., \& Mamiya, L. H. (1990). The black church in the African American experience. Duke University Press.

Mahdi, S., Ghannam, O., Watson, S., \& Padela, A. I. (2016). Predictors of physician recommendation for ethically controversial medical procedures: Findings from an exploratory national survey of American Muslim physicians. Journal of Religion and Health, 55(2), 403-421. https://doi.org/ 10.1007/s 10943-015-0154-y

Marx, K. (1844/1978). Alienated labor: The economic and philosophic manuscripts of 1844. New York: W.W. Norton \& Company.

McCoy, C. A. (2020). The social characteristics of Americans opposed to vaccination: Beliefs about vaccine safety versus views of US vaccination policy. Critical Public Health, 30(1), 4-15. https://doi.org/10.1080/09581596.2018.1501467

McPhetres, J., Jong, J., \& Zuckerman, M. (2021). Religious Americans have less positive attitudes toward science, but this does not extend to other cultures. Social Psychological and Personality Science, 12(4), 528-536. https://doi.org/10.1177/1948550620923239

McPhetres, J., \& Nguyen, T. V. T. (2018). Using findings from the cognitive science of religion to understand current conflicts between religious and scientific ideologies. Religion, Brain \& Behavior, 8(4), 394-405. https://doi.org/10.1080/2153599X.2017.1326399

McPhetres, J., \& Zuckerman, M. (2018). Religiosity predicts negative attitudes towards science and lower levels of science literacy. PLoS ONE, 13(11), e0207125. https://doi.org/10.1371/journal. pone. 0207125

Mohan, S., Reagu, S., Lindow, S., \& Alabdulla, M. (2021). COVID-19 vaccine hesitancy in perinatal women: A cross sectional survey. Journal of Perinatal Medicine. https://doi.org/10.1515/ jpm-2021-0069

O’Brien, T. L., \& Noy, S. (2015). Traditional, modern, and post-secular perspectives on science and religion in the United States. American Sociological Review, 80(1), 92-115. https://doi.org/10. $1177 / 0003122414558919$

O’Donnell, C. M., Black, N., McCourt, K. C., McBrien, M. E., Clarke, M., Patterson, C. C., \& Shields, M. O. (2019). Development of a Core Outcome Set for studies evaluating the effects of anaesthesia on perioperative morbidity and mortality following hip fracture surgery. British Journal of Anaesthesia, 122(1), 120-130. https://doi.org/10.1016/j.bja.2018.08.017

Olagoke, A. A., Olagoke, O. O., \& Hughes, A. M. (2021). Intention to vaccinate against the novel 2019 coronavirus disease: The role of health locus of control and religiosity. Journal of Religion and Health, 60(1), 65-80. https://doi.org/10.1007/s10943-020-01090-9

Page, R. L., Peltzer, J. N., Burdette, A. M., \& Hill, T. D. (2020). Religiosity and health: A holistic biopsychosocial perspective. Journal of Holistic Nursing, 38(1), 89-101. https://doi.org/10.1177/ 0898010118783502

Pennycook, G., Cheyne, J. A., Seli, P., Koehler, D. J., \& Fugelsang, J. A. (2012). Analytic cognitive style predicts religious and paranormal belief. Cognition, 123(3), 335-346. https://doi.org/10. 1016/j.cognition.2012.03.003

Pew Research Center. (2014). Religious Landscape Study. Retrieved August 25, 2021 (http://www. pew forum.org/religious-landscape-study/).

Piltch-Loeb, R., Silver, D., Kim, Y., Norris, H., McNeill, E., \& Abramson, D. (2021). Determinants of the COVID-19 Vaccine Hesitancy Spectrum. medRxiv. doi: https://doi.org/10.1101/2021.08. 05.21261675 
Plohl, N., \& Musil, B. (2021). Modeling compliance with COVID-19 prevention guidelines: The critical role of trust in science. Psychology, Health \& Medicine, 26(1), 1-12. https://doi.org/10.1080/ 13548506.2020.1772988

Ransford, H. E., Carrillo, F. R., \& Rivera, Y. (2010). Health care-seeking among Latino immigrants: Blocked access, use of traditional medicine, and the role of religion. Journal of Health Care for the Poor and Underserved, 21(3), 862-878. https://doi.org/10.1353/hpu.0.0348

Sallam, M. (2021). COVID-19 vaccine hesitancy worldwide: A concise systematic review of vaccine acceptance rates. Vaccines, 9(2), 160. https://doi.org/10.3390/vaccines 9020160

Schieman, S. (2010). Socioeconomic status and beliefs about God's influence in everyday life. Sociology of Religion, 71(1), 25-51. https://doi.org/10.1093/socrel/srq004

Schieman, S., Bierman, A., \& Ellison, C. G. (2010). Religious involvement, beliefs about God, and the sense of mattering among older adults. Journal for the Scientific Study of Religion, 49(3), 517-535. https://doi.org/10.1111/j.1468-5906.2010.01526.x

Schieman, S., Bierman, A., \& Upenieks, L. (2018). The powerful other: How divine control shapes the relationship between personal control and psychological distress. Journal for the Scientific Study of Religion, 57(1), 123-138. https://doi.org/10.1111/jssr.12502

Schieman, S., \& Jung, J. H. (2012). "Practical divine influence": Socioeconomic status and belief in the prosperity gospel. Journal for the Scientific Study of Religion, 51(4), 738-756. https://doi. org/10.1111/j.1468-5906.2012.01682.x

Schieman, S., \& Plickert, G. (2008). How knowledge is power: Education and the sense of control. Social Forces, 87(1), 153-183. https://doi.org/10.1353/sof.0.0065

Schieman, S., Pudrovska, T., \& Milkie, M. A. (2005). The sense of divine control and the self-concept: A study of race differences in late life. Research on Aging, 27(2), 165-196. https://doi.org/ 10.1177/0164027504270489

Schieman, S., Pudrovska, T., Pearlin, L. I., \& Ellison, C. G. (2006). The sense of divine control and psychological distress: Variations across race and socioeconomic status. Journal for the Scientific Study of Religion, 45(4), 529-549. https://doi.org/10.1111/j.1468-5906.2006.00326.x

Schwadel, P. (2011). The effects of education on Americans' religious practices, beliefs, and affiliations. Review of Religious Research, 53(2), 161-182. https://doi.org/10.1007/s13644-011-0007-4

Shenhav, A., Rand, D. G., \& Greene, J. D. (2012). Divine intuition: Cognitive style influences belief in God. Journal of Experimental Psychology: General, 141(3), 423-428. https://doi.org/10.1037/ a0025391

Sherkat, D. E. (2011). Religion and scientific literacy in the United States. Social Science Quarterly, 92(5), 1134-1150. https://doi.org/10.1111/j.1540-6237.2011.00811.x

Sinding-Bentzen, J. (2019). Acts of God? Religiosity and natural disasters across subnational world districts. The Economic Journal, 129(622), 2295-2321. https://doi.org/10.1093/ej/uez008

Smith, C. (2007). Why Christianity works: An emotions-focused phenomenological account. Sociology of Religion, 68(2), 165-178. https://doi.org/10.1093/socrel/68.2.165

SteelFisher, G. K., Blendon, R. J., \& Caporello, H. (2021). An uncertain public-encouraging acceptance of Covid-19 vaccines. New England Journal of Medicine, 384(16), 1483-1487. https://doi. org/10.1056/NEJMp2100351

Steensland, B., Robinson, L. D., Wilcox, W. B., Park, J. Z., Regnerus, M. D., \& Woodberry, R. D. (2000). The measure of American religion: Toward improving the state of the art. Social Forces, 79(1), 291-318. https://doi.org/10.1093/sf/79.1.291

Sullivan, L. S. (2020). Trust, risk, and race in American medicine. Hastings Center Report, 50(1), 18-26. https://doi.org/10.1002/hast.1080

Upenieks, L., \& Schieman, S. (2021). The belief in divine control and the mental health effects of stressful life events: A study of education-based contingencies. Review of Religious Research, 63(2), 183-215. https://doi.org/10.1007/s13644-020-00426-X

Upenieks, L., Schieman, S., \& Bierman, A. (2021). Jitters on the eve of the great recession: Is the belief in divine control a protective resource? Sociology of Religion. https://doi.org/10.1093/ socrel/srab018

Van Tubergen, F., \& Sindradottir, J. I. (2011). The religiosity of immigrants in Europe: A crossnational study. Journal for the Scientific Study of Religion, 50(2), 272-288. https://doi.org/10. 1111/j.1468-5906.2011.01567.x

Viswanath, K., Bekalu, M., Dhawan, D., Pinnamaneni, R., Lang, J., \& McLoud, R. (2021). Individual and social determinants of COVID-19 vaccine uptake. BMC Public Health, 21(1), 1-10. https:// doi.org/10.1186/s12889-021-10862-1 
Wallston, K. A. (2005). The validity of the multidimensional health locus of control scales. Journal of Health Psychology, 10(5), 623-631. https://doi.org/10.1177/1359105305055304

Washington, J. M. (1994). Conversations with god: Two centuries of prayers by African Americans. HarperCollins.

Webb, N. S., Dowd-Arrow, B., Taylor, M. G., \& Burdette, A. M. (2018). Racial/ethnic disparities in influenza vaccination coverage among US adolescents, 2010-2016. Public Health Reports, 133(6), 667-676. https://doi.org/10.1177/0033354918805720

Whitehead, A. L., \& Perry, S. L. (2020). How culture wars delay herd immunity: Christian nationalism and anti-vaccine attitudes. Socius, 6, 2378023120977727. https://doi.org/10.1177/23780 23120977727

Wilder-Smith, A., \& Freedman, D. O. (2020). Isolation, quarantine, social distancing and community containment: Pivotal role for old-style public health measures in the novel coronavirus (2019nCoV) outbreak. Journal of Travel Medicine. https://doi.org/10.1093/jtm/taaa020

Williams, D. R., \& Mohammed, S. A. (2009). Discrimination and racial disparities in health: Evidence and needed research. Journal of Behavioral Medicine, 32(1), 20-47. https://doi.org/10. 1007/s10865-008-9185-0

Wu, E. C., \& Cutright, K. M. (2018). In God's hands: How reminders of God dampen the effectiveness of fear appeals. Journal of Marketing Research, 55(1), 119-131. https://doi.org/10.1509/jmr.15.0246

Publisher's Note Springer Nature remains neutral with regard to jurisdictional claims in published maps and institutional affiliations. 